\title{
Analogical associations in the frame of a "neoclassical" semiotic theory
}

\author{
Guido Ferraro \\ Department of Philosophy, University of Turin \\ Via S. Ottavio 20, 10124, Torino, Italy \\ e-mail: guidfer@katamail.com
}

\begin{abstract}
It has been a long time since the concept of iconic signs was proposed by C. S. Peirce. From that time on, we have been increasingly realizing that semiotic systems are for the most part established just on some type of similarity. But the more we see the sphere of analogical signification expanding its realm, the more we become aware of how inadequate is the notion of a simple relationship connecting locally a physical object with a second object, or with a mental entity. There is, on the other hand, the more refined theory of sign conceived by Ferdinand de Saussure, but this theory, by its very definition, addresses a restricted domain, and definitely does not include the field of those signs which rest on analogical associations.

The main purpose of this article is then to show how the more polished Saussurean model can act as a starting point for a general restatement, primarily intended to embrace the signs that rest on an analogical basis. We may so speak of a "neoclassical", innovative semiotic theory, able to join the latest "sociosemiotic" approach with the most precious foundations of our discipline.
\end{abstract}

\section{A different view on semiotic analogies}

There is no doubt that semiotics has suffered a lot due to so many ambiguities about concepts such as "analogy", "similarity" or "resemb- 
lance". Primarily, as we shall see in the next pages, we have to face unsatisfactory theoretical models concerning the semiotic correlations which rest on an analogical basis: more or less what traditional Peircean terminology calls "icons". More generally, it seems unacceptable that, after a century from the establishment of the discipline, we still cannot refer to a unified theory about the most fundamental semiotic relations.

Referring to an idea of semiotics fully conceived as a social science (a "sociosemiotics", according to the term nowadays largely used, mainly in Italy and in France), I think that we have to refer more closely to the perspective originating from Durkheim and Saussure. In the first instance, we can rethink the original Saussurean model in new terms, more consistent with the ways of seeing that we feel distinctive of social sciences. I am referring here to the perspective of a social foundation of semiotic systems, as in the Saussurean definition of "semiology", or to the idea of a constitutive role of languages and symbolic systems in the very establishment of a social structure, as in the thought of Émile Durkheim. ${ }^{1}$

The main purpose of this article is to show how the more polished model by Ferdinand de Saussure, usually restricted to the linguistic field, can instead act as a starting point for a general restatement, primarily intended to embrace the signs which rest on an analogical basis. I can only mention here what we owe to scholars such as Claude Lévi-Strauss or Luis Prieto, who both reworked some facets of the Saussurean thought, in a perspective more consonant with the vision of a social science. ${ }^{2}$

First of all, we have to remark that any possible way of defining correlations of signs involving "analogies" runs into the multiplicity of

\footnotetext{
1 See mainly his seminal work on symbolism, where languages play an essential part in a sociological reworking of the Kantian model (Durkheim 1912).

2 For an in-depth discussion of the sign model in Lévi-Strauss, see Ferraro 2001; a shortest exposition can be found at www.etnosemiotica.it/programma_giornata levi_strauss_guido_ferraro_levi-strauss_un_maestro_per_una_strada_ancora_da_ percorrere_contributo.php. For Prieto's model, see Prieto 1975.
} 
different operations, different functions, different semiotic ranks that analogies may assume. On the other hand, there is no doubt that semiotics, from its very beginning, focused on the problematic crux concerning the interrelated concepts of identity, difference, and analogy. It is revealing to note how Saussure stressed the absolute centrality of analogical mechanism in language: central with regard to diachronical modifications, ways of learning our own tongue, and to morphological structuring, too. As he said, "every language at any time is nothing else but a whole of analogical patterns" (Saussure 2002: 161). On the other hand, when he speaks about signs' identity, he disassembles the apparent level of analogies - "positive" relations, seemingly recognizable in the "things" themselves - pulverizing them in a mere illusionistic effect of what are the actual constitutive bricks of language: negative and differential relations. Well known is the case of the many possible ways of tracing the letter " $t$ " in the Roman alphabet: if we have become used to saying that those graphic traces, even if objectively dissimilar, are effectively equivalent, this is not on account of what makes them positively similar, but on account of the differences they share, with regard to other units belonging to the same system.

Keeping up a tradition starting from Saussure and later deepened, among others, by Luis Prieto (1975), we must therefore think that the different ways of manifesting a signifier are not equivalent because they are inherently similar, but that on the contrary they look similar because we assign them the same distinctive features, and accordingly we regard them as equivalent and interchangeable. From the point of view of a speaker, the effect of analogy is so immediately evident as to determine precisely the naive impression that the likeness is "in the things themselves", and that the likeness could be the source, not the effect, of an assignment of identity. The analogies we perceive are actually the result of the work of semiotic systems: consequently, there cannot be any semiotic system "founded" on analogies, but systems that build and work out analogies in different ways. 
As we know, what applies to the signifier, applies to the signified in the same way. As the word "blue", uttered by different voices, produces sounds objectively different - but we always subjectively recognize "the same word" - so the chromatic representations coming under the category of "blue" are definitely different, but we feel them as "similar" - when objectively they are not. Of course, as we all are familiar with the experience of at least one second tongue, we know that people speaking different tongues have partly different perceptions about what is "similar" and what is "different", just because such an effect of similarity is created by the system.

In our straight relation with the surrounding world, we are always dealing with differences between things. There never was an ingenuous time when we naïvely lived in a world of magical analogies, as Lucien Lévy-Bruhl (1910) could suppose, nor is it a matter of a specific "postmodern" inability to recognize analogies, as in the perspective of Barbara Maria Stafford. ${ }^{3}$ The focal point is, for us, that a system of signs - every system of signs, of any kind! - cannot work if not producing effects of similarity, starting from what actually is a network of differences. Usually, we do not underline enough the primary fact that any semiotic system - even if it has nothing to do with "iconism" - relies on a mechanism in some respects based on analogies: a consideration which partly explains the numerous confusions and perplexities in the theoretical treatment of the concept of "analogy". In effect, as every system of signs rests on correlations between classes (on both sides of signifier and signified), and the common belonging to a class creates such a strong effect of "similarity", it follows that in all systems of signs the upshot of similarity always plays a leading role.

In order to distinguish this type of similarity from other, different types, I propose to employ the expression "equi-similarity". So, "equi-

\footnotetext{
3 "Today, however, we possess no language for talking about resemblance, only an exaggerated awareness of difference" (Stafford 1999: 10).
} 
similar" are those entities that are perceived as analogous because they are semiotically equivalent, as possible ways of realizing the same signifier (as in the case of the many different ways of writing the letter " $t$ "), or the same signified (as in the case of the many chromatic representations that belong to the signified of the term "blue").

The core of the "classic" semiotic view could then be stated as follows: signifier and signified should be conceived of as categorical structures set at a high level in the cognitive hierarchy. Operating into discursive practices, they generate working sets that are respectively sets of expressive variants (for the signifiers) and sets of senses (for the signifieds). The expressive variants manifest themselves in perceptible objects (sounds, colors, static or moving shapes, and so on), while on the other hand the specific senses find a definite correspondence in psychological entities (mental representations, emotional conditions, and so on).

This "classical" theoretical model is not only stylish and refined but also operationally effective, and attentive to the functional dimensions of signs. Moreover, it is capable of linking very well the relational dynamics operating at the systemic level with the psychological reality that signs take in the mind of speaking people. For these reasons, it should be definitely preferred to the reworking carried out by Louis Hjelmslev, that is too abstract and unrealistic from the very beginning, and later overwhelmed by too many inconsistent exploitations. ${ }^{4}$ The main problem is that, in its original view, the "classical" model was conceived exclusively for the arbitrary signs, a case unquestionably very relevant but also quite atypical. The idea on which this article is founded is that there are no actual reasons to exclude the validity of

4 See the critical attitude taken by Luis Prieto (1975), and more recently by François Rastier (2001: 58, ff). Concerning inconsistent exploitations, everyone could cite some examples, but I could start remembering a classical review by Cesare Segre, evaluating the many different and "hazardous" suggestions around what could match the Hjelmslevian quadripartion in the domain of literature (chapter on Text in Segre 1985). 
this model in any other semiotic field, in the framework of what I call a neoclassical perspective.

\section{Equi-similarity in the world of indices}

A good starting point for such an extension can be thinking how this model could be adapted for those signs that the Peircean tradition calls "indices". We know that a certain aura of oversimplification in the more popular definitions of those concepts are due to successive trivializations, but it is undeniable that their source is in the actual writings of the author. If we take into account the effective way we read indices in our surrounding reality, we can notice how we rely on our very essential habit of moving inside chains of events; but, if we examine the matter carefully, it is not a question of single events: we are building on settled patterns of events, structures set at a higher level (scripts, if you want).

As in the perception of our experience of life, according to models that we learn to apply in our very first months of life, events are linked together in a sequence, this allows us to go back logically, passing from a link in the chain to another: something roughly similar to what in semiotics is called a "syntagmatic chain". The form of the chain allows to both go upstream, from the effect to the cause (common examples are: from the footprint in the snow to the passing of the bear, or from the smoke to the fire, etc.), or to go downstream, from the cause to the effect (from the black clouds to the likelihood of rain). This is valid for "natural" signs, as well as for human indexical behavior: if a lady wears very expensive clothes, this is the result of available money (upstream connection), while if it happens that our interlocutor is insistently looking at his watch, a downstream connection allows us to read his behavior as expressing a concern for a flow of time which leads him towards a subsequent occurrence. 
A typical pitfall is to think that the link between the index and its value sits at a local level. But what is happening in our mind when we see a black cloud in the sky, or a footprint in the snow, or a person who is insistently looking at his watch, is very much alike to what happens when we hear a word uttered. We do not operate a link between the perceived object and its meaning, but between the object we are perceiving and the class it belongs to. Physically, what I am seeing is a black cloud, or a person looking at his watch, but my interpretation of the specific perceived object or event arises because I recognize it as a particular occurrence of a general model: what carries for me the significance of "likelihood of rain" is not that specific black cloud which is now here in the sky (it is not a sign, then!), but the general class of black clouds which is stored in my mind. This is definitely far from the common version of the Peircean theory, where an index is something that has a real, physical connection with an object. "The index has no generality in itself. It does not depend on a mental association" (WP 5: 379). But in the same article Peirce suggests that index can also be seen as a token of a general connection, as it happens when I know that it is raining because I notice a number of people with their umbrellas up (the open umbrella asserts rain by virtue of a "mental association", ibid.). So we are probably not too far from other, brighter aspects of Peircean thought, when we propose that an index works in conformity with the "classical" model; its signifier is not a single object at a local level (a cloud, for instance), but a model - in Saussurean terms, the "mental image" - which brings together all the possible, equi-similar black clouds: a mental entity of general value, of which the cloud I am seeing now is nothing but a local manifestation. All the possibilities of rain are "similar", as all the black clouds are "similar": the indexical relations cannot be grasped leaving aside the form of likeness that I call "equi-similarity".

The triangulation objectual representamen $\rightarrow$ interpretant $\rightarrow$ object can therefore be usefully replaced with the more unequivocal and better developed quadripartite structure: physical or textual immediate 
entity $\rightarrow$ signifier (general class) $\rightarrow$ signified (general class) $\rightarrow$ specific mental content (it should be stressed that there is no acceptable correspondence here between Peircean and Saussurean categories). This model, as well as being more explanatory, matches better the psychological truth of what is actually happening in my mind when, in the above-mentioned case, I see a black cloud: the semiotic functioning of our mind follows correlations between classes, not between single objects.

Now, we have to wonder if something like that can be true also for iconic correlations, that is, for semiotic correlations based on the establishment of an analogical link - here again in conflict with the Peircean principle denying generality to icons. However, we have to preliminarily remark that we are facing a huge and variegated universe. In fact, apart from language and its derived semiotic systems (primarily the alphabetical writing), almost all our expressive tools rest on an analogical ground. First of all, we have to go beyond the idea of a coincidence between analogical signification and visual expression. I agree with what Göran Sonesson (1994: 74) wrote: "in Peirce's view, there is nothing intrinsically visual about iconicity". So, we can see an analogical way of working in systems not strictly nor exclusively visual, like theatre, cinema and television, but also in systems that have nothing to do with the visual, like poetry, music, or the field - in its own right huge and diversified - of narrative production. Even though here we'll stick to visual instances, and more specifically to photographic or cinematographic images, we'll do so with the awareness of the extent and multiplicity of all that belongs to forms of semiosis based on analogical correlations.

\section{A light in the dark}

According to what I consider the brighter view of Peircean thought, the sign reference exists only in the mind of an interpreter, a "some- 
body" ("A sign, or representamen, is something which stands to somebody [...]" CP 2.22), whether we assume "somebody" as an individual or as a social entity ("we know that man is no whole as long as he is single, that he is essentially a possible member of society. [...] It is not "my" experience, but "our" experience that has to be thought of; and this "us" has indefinite possibilities", CP 5.402). Commenting on this passage, Peter Skagested (2004: 245) maintains that "communication, to Peirce, is the context in which thoughts are formed, and is logically prior to thinking processes taking place in individual minds": a perspective which indeed shows remarkable affinities with the views both of Durkheim and of today's sociosemiotics. In any case, the icon may be regarded as resting on a subjective judgment of resemblance; the resemblance is not in the things themselves but in the way a person, or a community, chooses to look at things. This basic assumption immediately underlines how any recognition of analogies implies an actual process of interpretation. But this conception is also capable of saving us from the common idea that analogy could link $a$ thing to another thing, making it easier to adopt the view that, also in the case of icons, the semiotic structure links two abstract and general mental configurations, the signifier and the signified.

Of course, some common examples, as those of photos made for identity cards or documentary images, present us with cases where there is no doubt that an image refers to a specific object in the world. This is an interesting and yet particular use, which assimilates the iconic signs to what in the language are the "proper nouns", designators of individual entities. But in most cases the ways we employ images are more complex, and in the semiotic real life the analogical configurations are conceived with expressive and interpretative aims, well beyond the aim of simply pointing to something there in the world.

It is not my aim here to discuss in detail the Peircean views about iconism, but I think they are too prone to a sort of "referential illusion", speaking in Greimas' terms. I remember here the classic example by Nelson Goodman (1968: 50): "Before me is a picture of 
trees and cliffs by the sea, painted in dull grays, and expressing great sadness". This picture "represents" things, but "expresses" certain feelings. According to Goodman, "a picture must stand for, symbolize, refer to, what it expresses" (Goodman 1968: 52). Although he does not embrace a fully semiotic view here, his idea about the meaning of a visual text is clearly of a metaphorical and emotional kind. Even more meaningful, Goodman claims that "representing is a matter of classifying objects rather than of imitating them, of characterizing rather than of copying, it is not a matter of passive reporting" (ibid, 31).

At this point, I think that we need an example, in order to better elucidate our matter. I choose a case quite subtle and refined, at first simple and evident but capable of showing how a sociosemiotic, systemic analysis can diverge from a textual inquiry, confined to a supposed local level. I will refer to the incipit of a film which manifests a special relevance from a semiotic point of view. The Sixth Sense, directed by M. Night Shyamalan in 1999, can be seen as a text about the ways we read our experience; moreover, anybody who saw it knows how the film plays with the reactions and the faults of its spectators, and with the slight boundary between what we see and what we know. The film incipit belongs to this subtle and meaningful game. Although almost nobody pays attention to it, at least when watching for the first time, the very opening of the text is an insistent shot which, for a full eighteen lengthy seconds, shows us an electric bulb gradually switching on, moving from total dark to light.

As (the author is right, indeed) we are actually fully miseducated to interpret what we see, we tend to take this shot as a somewhat stylish way of starting the story, immediately consenting to its prompt diegetic justification: it's the lighting of a cellar, where the wife of the main character is going to take a bottle of wine, in order to celebrate a special occasion. But if we pay more careful attention, we realize that the bulb turning on in the dark can be understood as an occurrence of a sign that, just in the beginning of the text, briefly points toward its 
main topic: this scene opens a film which is going to tell us about how we may be able to find out things that at first seem incomprehensible.

Once started up, the interpretation machine, in this case, works really easily, all the more so because, say, both the world of comic strips or the one of common speech are full of "bulbs switching on", not to speak, of course, of our ordinary direct experience of a lamp which, giving light to a dark space, makes it possible for us to find out what just a moment before was indiscernible. Therefore, the viewers can assign a meaning to that light because they have already seen other lights, from life or in drawings, and furthermore they have heard people speaking about metaphorical lights that "switched on in their minds", and so on. This means that, if that specific bulb is located inside the film, it is nevertheless nothing but a member of a larger class, known through different ways. So, we are facing a token of a culturally established type: the type "light coming on in the dark", with its meaning "process that conveys a knowledge in an area that was previously unclear". This general model is located not in the film but in the cultural system.

\section{Where analogies live: beyond text-oriented semiotics}

So, we understand that there is a fundamental alternative between two greatly different modes of conceiving the sign. The first perspective assumes that semiotic relations are entities located inside the texts, and that therefore texts could be seen as "composed of signs". As this view is not so easy to sustain, text-oriented semiotics (Greimas in the first place) often appears as fluctuating between two options. On the one hand, we notice a not fully rationalized tendency to laying aside the troublesome notion of "sign", along with the incorrect relegation of 
signs in the realm of "manifestation". ${ }^{5}$ On the other hand, we see the actual identification of "signs in the text" as primary constituents of the semiotic backbones, especially evident in the analysis of Maupassant (Greimas 1976).

The other perspective, not textual but culture-oriented, is the one I call "neoclassical", specifically conceived for the current sociosemiotic line of studies. In this view, we assume (as Saussure) that the level of existence for the semiotic relations is the same as the level of cultural systems. From this point of view, what sign structures have in the texts is a specific application and occurrence. As we can see, this is nothing more than a generalization of the well known (in linguistics) assumption that words, the morphemes, have their existence in a collectively shared system (the langue), having in the sentences their specific occurrences. In Peirce's terms, we could say that it should be sufficient to generalize to every kind of sign what the author said about symbols (such as in CP 2.249), stating that every sign signifies by virtue of a law, on the strength of an association of general ideas, hence qualifying as "a general type or law, [...] a Legisign".

Of course, this way of seeing deeply transforms our approach to textuality. Sure, in every semiotic system the specific textual realizations show inevitable and constitutive variations. In fact, also in the case of our example we are able to envisage a broad range of possible variants: instead of an electric bulb, we could see the headlights of a car, an electric torch, or maybe the rays of a rising sun. These variants can turn out to be interesting, and perhaps to be capable of adding some color, but they still remain variants that carry a common meaning and can therefore substitute each other. Thus, these different kinds of light constitute a case of what we call "equi-similarity", and consequently a class of entities capable of expressing the same concept; therefore, they set up what we call a "signifier", culturally linked to a given signified. At a theoretical level, we understand now that the

See the entry Signe in the Dictionnaire by Greimas and Courtés (1979). 
signifier is not what we saw in the film, but the cultural entity that manifests itself in a specific mode in the film. But the trick is that, as we fall into the illusion to see "words" in a sentence, so we believe we are seeing icons in a film, or in a painting. As it often happens, we take the reflections for the real thing, but it has to be this way in our direct experience of texts: the illusion is part of the game.

Furthermore, the idea that things possess an intrinsic identity, so that their classification is objectively achieved, is a part of the same illusion. On the other hand, an act of classification is subjective and creative. As Nelson Goodman (1968: 32) states, a classification involves choices, so that, he says, the making of a picture is someway a manner of making the object which is pictured. If you want to know how Shyamalan develops the idea that we found at the very beginning of the film, well his central point is just that we tend to refer everything we see back to already known categories, a way of behaving which could stop any inventiveness and any discovery. We have to be open to what can surprise us, be willing to attach importance to relevant differences, and so be ready to reorganize our knowledge. As we see in the film, we can learn a lot from other people and their different ways of viewing. Therefore, we should bear in mind that classifications are temporary and relative, negotiated and intersubjective; they can be as much conservative as innovative; it is the duty of the arts to show us that there are different ways of categorizing the world.

If we now want to make fully explicit the reason why a light switching on in the dark can be seen as a token of a signifier (a signifier related to a certain concept), there is no doubt that we are facing an association based on analogy: straightforwardly, the dark metaphorically expresses the concept of "ignorance", as the light expresses the concept of "knowledge", so that darkness and ignorance on the one hand, and coming of light and opening of knowledge on the other hand, constitute two couples of analogs. And here, too, the effect of analogy (a culturally constructed analogy, of course) rests on 
a differential ground: darkness and light take their meaning merely in their contrast, better said in the apparatus of differences and transformations where one is denied when the other is asserted.

The relation that, for instance, connects the darkness to ignorance, links an entity on the side of the signifier with an entity on the side of the signified. This is for us an actual case of a semiotic relation established upon an effect of analogy: we may call this type of analogy, to have a concise expression, "rel-analogy". As we saw - and as schematized in Fig. 1 - equi-similarity puts together variants belonging to the same whole (on the side of the signifier or on the side of the signified), and is therefore valid for every type of signs, while the rel-analogy is a specific kind of connection between signifier and signified, defining a specific type of signs (roughly what tradition calls "icons"): signs resting on associative correlations, in the sense that will be now better specified. Moreover, unlike equi-similar variants, the rel-analogous terms are not reversible: the darkness, which is an entity that can be easily manifested (textualized) in a perceivable and physical way, stands for an abstract concept as "to not know" or "to not understand". Similarly, we can use a map as standing for the configuration of a territory, but there couldn't be any sense in using a territory as standing for a map. ${ }^{6}$ In general terms, we always see that the single case stands for the general type, the part for the whole, and so on. What's involved, then, is not a mere relation of similarity, as this connection implies a dissymmetry too, between simple and complex. We know very well that a map is useful just because it shows a schematization, reduced and simplified. But it is the same for a pictorial representation, that is always more essential in comparison with the represented scene or person: a reduction where, it has to be noted, a quantitative less corresponds to a more of significance and

6 This type of dissymmetry has already been remarked; see Wallis 1973 and Sebeok 1976: 128. Göran Sonesson has discussed the question in detail, see Sonesson 1994, 1998. 
intelligence. Also in the case of a photograph - which could represent here a kind of extreme - we may notice that the image of better quality and greater meaning is often the one which performs the more severe subtraction in comparison with the scene it depicts. ${ }^{7}$

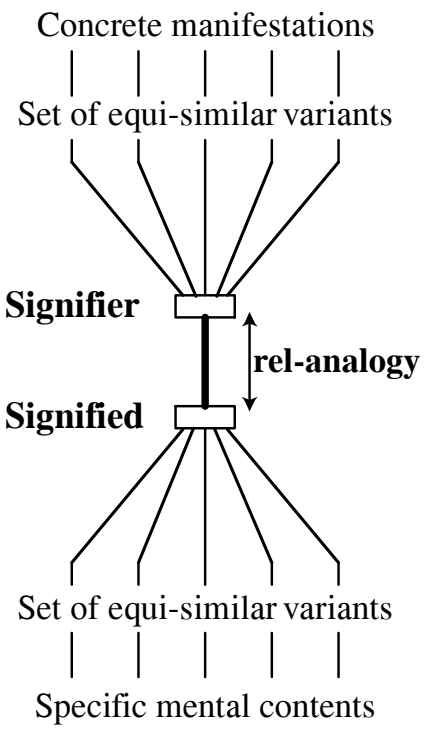

Figure 1. Rel-analogy and equi-similarity.

7 It is interesting to notice how this is a widespread idea, common also in popular handbooks for photography enthusiasts. See for instance: "Making camera photographs involves the practice of subtractive thinking. [...] Imagine being a sculptor of images who chips away at a monolithic block of reality until only what is absolutely necessary remains and then relies on each viewer to fill in the missing pieces to complete the meaning" (Hirsch 2008: 34-35). 


\section{Let the sense happen}

So, the iconic elaboration condenses portions of the real, of the imaginary or of the conceivable, offering us a simplified image or, as we may also say, a model. This is an essential fact if we want to explain why we use forms of analogy in such an insistent and ubiquitous manner. Moreover, it must be emphasized that the analogical arrangement of our representation of the world does not indicate any mental simplicity or naivety, but a complex and refined thought. The forms of analogical association can reach modes of extreme subtlety and ductility, including calculated ways to produce polysemous values, which have little to do with the proverbial "constitutive ambiguity of the image". Furthermore, the analogical connections are not restricted to "similarities" in a strict sense, but include cases such as the one which moves from an allusion to its reference, the modes which govern synesthetic connections and formal parallelisms, and so on. Analogical correlations may have a figurative nature or, as they say, a "plastic" one; they may stick to limited points in the text or rely upon features recurring in different parts (something like what Umberto Eco calls expressive textures (Eco 1976: 210)). This articulated variety of means still remains to be defined and analyzed, in the updated viewpoint of a grammar of the forms of analogical expression.

A very effective type of analogical association (roughly corresponding to traditional "synecdoche") is the one which links the single case to the whole it belongs to, a modus operandi common in photography, for instance in the field of reportage. This procedure allows analogical communication to operate through "scraps": a form of great efficiency, able to thicken semantic values using, in a sophisticated manner, both types of analogy we are talking of. Let's see how it works. Schematically, the photographer investigates a given situation (a war scenery, an urban area presenting a particular social characterization, and so on), trying to understand it, sorting out the most relevant aspects, and so developing a mental interpretation - 
which is, in practice, the meaning he therefore set himself to express. In this first phase, then, he is going from the observed world towards a constructed meaning. At this point, he will try to define how, extracting a scrap, or a facet, from the observed reality, and giving it a definite visual arrangement, it is possible to give rise to a proper support for the intended communicative performance. Now he is going from the side of the signified to the side of the signifier, indeed: so that the superficial "reference" of the image to the "real" is a mere appearance, if not a deceptive effect.

It should be noted at this point how the legitimacy of this gesture of cutting out a fragment from the whole rests on the assumption that the portion of reality specifically caught in the photograph is not anomalous or uncharacteristic, since in such a case it could be seen as a deception. In principle, what is cut out should be comparable to other portions (in our terms, be "equi-similar" to them), and ultimately equivalent to the whole - what in current speech we call "to be representative". Both in the relation part-to-part as in the relation part-to-whole, we see in action forms of equi-similarity that are far from being either simple or obvious. I mean that the author makes us understand that the photograph he produced could be semiotically equivalent to other photographs that, in the same place, he or someone else could have produced, as variants of a structured signifier that brings us a given concept (the intolerable cruelty of war, for instance).

Perhaps, considering the example of the electric bulb, you could have thought that our theoretical model could apply only to images working as symbols or metaphors, but not to images more bound to a "real" starting point, like in the realm of journalism. But, if we give it a more serious attention, in the case of reporting, too, the making of every image departs from a meaning that has to be expressed. Sure, to the exclusion of instances where strictly, and maybe almost compulsory, someone set oneself "not to say anything". But of course, if there is an image fully devoid of any meaning, a mere impersonal replica of 
an object, it should be considered as not pertaining to the semiotic domain.

Be they symbolic images or photographic reportages, visual portraits or grasps of some magic landscape, the analogical representations obey in any case the theoretical model that we tried to propose, with the aim of recovering an effective and brighter way to explain semiotic processes. "Processes", it should be emphasized. Let us see why. If we go back to our reporter, we realize that what he presents is not just an "image of something". Now, this is the point: the very meaning of his "to be there", together with his way of looking and comprehending, selecting and framing, bounding and arranging, and his capability in processing things so as to make visible what hardly should be seen by a direct look, and finally his way of giving assurance about representativeness and equivalence... this whole sequence of steps and procedures, pacts and guarantees, all that, truly, is engraved in the image he is showing us, all that is exposed and presented as a part of the apparatus that ultimately sets up its meaning.

We perceive the reasons of his clipping, the logic of his choices, his search for that specific perspective, and so on. As John Berger pointed out, every time we look at a photograph, we are aware of the photographer selecting that sight; photographic images do not show things, but relations between things and observers (Berger 1972: 9-10). Not far from here are the words by Philippe Dubois (1983: 9): "avec la photographie, il ne nous est plus possible de penser l'image en dehors de l'acte qui la fait être". . Most images, as again John Berger (1995) said about photographs, look as quotations of reality; but it should be added that they are mainly pointing out just the ideal marks indicating the quotation. Under any creation of an analogical reference, peeps out a smouldering metasemiotic dimension ("Look: this is a way someone made this image...").

\footnotetext{
8 "dealing with photographs, we cannot any more consider the images outside the action that creates them"
} 
Here is one of the most remarkable differences between index and icon. While both seem to have a story to tell, nevertheless the index often pretends innocence and unintentionality, as if it was the footstep left behind by a mechanical device. The analogical sign tends instead to emphasize that it is intentionally made, showing off its process of construction and the manners (the rules) of its specific practice of production. We cannot understand unless we mentally repeat its course; we cannot discover its meaning unless we make its sense happen.

\section{Making the world thinkable and the ideas visible}

This brings us to a last, crucial consideration. Let us go back to our example of the electric bulb switching on, in the incipit of the Sixth Sense. We gave to those images a perhaps convincing reading, but could they have more, different readings? Let us say that, looking to this black screen gradually brightening, we can definitely see an allusion to the very same process of the film projection: an assumption sustained by many subsequent mentions to the power of recorded images, or sounds, and by the amazingly symmetrical finale, where the image vanishes in a fully white light (as the protagonist - thanks also to another film showing inside the film - eventually realizes the unreachable and terrible truth).

Then, could we say if the "right interpretation" is the one mentioned before (Topic: how we can understand the world), or the one suggested now (Topic: how cinema creates a representation of life)? Or perhaps the first one is a partial and provisional reading, and the latter brings us to the ultimate meaning? We could instead assume that crucial is just the way the analogical references stratify in parallel: this film talks about how knowledge arises, but cinema is in its own a vehicle of knowledge; the deepest meaning is in the concurrence of different levels: light equals knowledge, light equals cinema, then cinema equals knowledge... 
If we take this path, we could also notice that the same story shows us how can we understand who we really are only passing through the eyes of someone else; but, again, cinema is not just a means to see with someone else's eyes? Looking elsewhere, in a different way, not quite being who we are, not exactly from here where we are... Actually, if you saw the film, you remember how the protagonist first reaches a fragment of the truth. He listens to a tape recording (very similar to an exposed film, isn't it?), but selecting just an "insignificant" fraction that he had never listen to, because there was "nothing" there, only "silence", as he was not there at the moment of recording. Looking elsewhere, not through our eyes, listening into the silence of our absence, finding the truth where we are sure there is no meaning, learning from the voices of missing people... or - it is another key episode in the film - discovering a murderer from the void, useless section of a video tape: multiple parallel and equi-similar segments (and we could easily add more of them). Which one "is the meaning", and which one is the mere vehicle of that meaning? We feel that the authentic meaning is not lying in a specific level, but in the same outline of their correspondence, and we could not tell the "authentic meaning", if not making use of another metaphorical vehicle: for instance, recognizing that knowledge is not merely "a light", but a light at the moment it is breaking the darkness, like a divergent, anomalous presence where its absence is rule. The meaning of all those episodes may be clear to our mind, but it does not reside somewhere in a specific level: it exists only in the analogy that intersects them all. But perhaps this could bring us to the best definition for the concept of "signified" in the case of a complex iconic sign: signified is the shared abstract logic that underlies all the different expressive variants, as a common conceptual form.

There is a theory about it, incomplete but fascinating, as this way of working of semiotic systems with an analogical basis has been studied in depth by Claude Lévi-Strauss, mainly in his books about American native mythologies. He lead us to think that such systems do not 
actually outline a final semantic plane, as their primary semantic value should better be seen in the same logical form through which they induce us to a certain way of reading the world, thanks to the logic of parallelisms they set up for us. With Lévi-Strauss' words, we could say that the meaning "is not in a privileged content, but in logical relations devoid of content" (Lévi-Strauss 1964: 246). I would be less extreme, but I think that analogies should be seen as more than a straightforward device to establish semiotic references: the cultural design that shapes the analogies we are lead to perceive, holds the order which rules our whole experience.

So, the general model of sign we talked about helps us to understand how iconic signs tend to make us perceive classes and crossings of analogical equivalence. While the usual model of icon considers it as a link between "this thing" and "that other thing" at a local and specific level, the actual outcome of analogical configurations seems to mainly move in a quite different direction. Even in the case of a photograph shot by a reporter in a definite place and situation, we are inclined to feel that, say, this child in the image had been put under our eyes not for what he personally is, but because he is similar to many other children, tormented in that war, a war whose cruelty is similar to the cruelty of any other war, and similar also to the cruelty of many other circumstances where violence overwhelms the innocent. A bitter truth, made visible in the face of this child, here and now. Our closing hypothesis is therefore that we use icons not just because of their aptitude to describe something but, more often than not, because of their powerful faculty of generalizing, categorizing, connecting, and so reassuring us that sense is not only thinkable in our mind but visible everywhere, widespread and truly present in the world: images do not show things, but thoughts. 


\section{References}

Berger, John 1972. Ways of Seeing. London: Penguin.

Berger, John 1995. Appearances. In: Berger, John; Mohr, Jean. Another Way of Telling. New York: Vintage Books, 81-129.

CP = Peirce, Charles S. 1931-1958. Collected Papers of Charles Sanders Peirce. Cambridge: Harvard University Press. [Hartshorne, Charles; Weiss, Paul (eds.), 1931-1935; vols. 7-8. Burks, A. W. (ed.) 1958; In-text references given as $\mathrm{CP}$, followed by volume and paragraph number].

Dubois, Philippe 1983. L'acte photographique. Bruxelles: Labor.

Durkheim, Émile 1912. Les formes élémentaires de la vie religieuse. Paris: Alcan.

Eco, Umberto 1976. A Theory of Semiotics. Bloomington: Indiana University Press. Ferraro, Guido 2001. Il linguaggio del mito. Valori simbolici e realtà sociale nelle mitologie primitive. Roma: Meltemi.

Goodman, Nelson 1968. Languages of Art. London: Oxford University Press.

Greimas, Algirdas J. 1976. Maupassant. La sémiotique du texte: exercices pratiques. Paris: Seuil.

Greimas, Algirdas J.; Courtés, Joseph 1979. Sémiotique. Dictionnaire raisonné de la théorie du langage. Paris: Hachette.

Hirsch, Robert 2008. Light and Lens. Photography in the Digital Age. Amsterdam: Elsevier.

Lévi-Strauss, Claude 1964. Le cru et le cuit. Paris: Plon.

Lévy-Bruhl, Lucien 1910. Les fonctions mentales dans les sociétés inférieures. Paris: Presses Universitaires de France.

Prieto, Luis J. 1975. Pertinence et pratique. Paris: Èditions de Minuit.

Rastier, François 2001. Arts et sciences du texte. Paris: Presses Universitaires de France.

Saussure, Ferdinand de 2002. Écrits de linguistique générale. [Simon Bouquet; Rudolf Engler (eds.)] Paris: Gallimard.

Sebeok, Thomas A. 1976. Contributions to the Doctrine of Signs. Bloomington: Indiana University Press; Lisse: Peter de Ridder Press.

Segre, Cesare 1985. Avviamento all'analisi del testo letterario. Torino: Einuadi. (=Introduction to the Analysis of the Literary Text. Bloomington: Indiana University Press, 1988).

Skagested, Peter 2004. Peirce's semeiotic model of the mind. In: Misak, Cheryl (ed.), The Cambridge Companion to Peirce. Cambridge: University Press, 241256. 
Sonesson, Göran 1994. On pictoriality: the impact of the perceptual model in the development of pictorial semiotics. In: Sebeok, Thomas A.; Umiker-Sebeok, Jean (eds.), Advances in Visual Semiotics. The Semiotic Web, 1992-93. BerlinNew York: Mouton de Gruyter, 67-105.

- 1998. That there are many kinds of iconic signs. Visio 1(1): 33-54.

Stafford, Barbara Maria 1999. Visual Analogy: Consciousness as the Art of Connecting. Cambridge: MIT Press.

Wallis, Mieczysław 1973. On iconic sings. In: Rey-Debove, Josette (ed.), Recherches sur les systèmes signifiants. The Hague: Mouton, 481-498.

WP $=$ Peirce, Charles S. 1982-1999 [1857-1890]. Writings of Charles S. Peirce: a Chronological Edition, 6 vols., Bloomington, Indiana University Press. [J. W. Kloesel (ed.), Peirce Edition Project; In-text references given as WP].

\section{Ассоциации, основанные на аналогии, в рамке «неоклассической» семиотической теории}

Много времени прошло с тех пор, как Чарльзом Пирсом было предложено понятие иконических знаков. Но чем шире становится поле обозначения на основе аналогии, тем более очевидным становится то, что концепция простой логической связи физического объекта с другим объектом или ментальным энтитетом недостаточна. С другой стороны, существует созданная Фердинандом де Соссюром более рафинированная теория знака, но она по существу направлена на более ограниченную область и не учитывает знаков, основанных на аналогии.

В статье показано, каким образом, исходя из теории Соссюра и ставя своей целью рассмотреть и знаки, основанные на аналогии, можно переформулировать теорию знаков. В итоге можно говорить о «неоклассической» инновационной семиотической теории, которая способна соединить в себе более поздний «социосемиотический» подход с основами нашей дисциплины. 


\section{Analoogiapõhised assotsiatsioonid „neoklassikalise” semiootikateooria raamistus}

Sellest kui C. S. Peirce pakkus välja ikooniliste märkide mõiste, on möödunud palju aega. Sealt peale oleme üha enam mõistnud, et semiootilised süsteemid põhinevad eelkõige mingit tüüpi sarnasusel. Ent mida enam me näeme analoogiapõhise tähistuse välja kasvavat, seda enam saame me teadlikuks sellest, kui ebapiisav on arusaam lihtsast suhtest, mis ühendab loogiliselt füüsilist objekti teise objektiga või mentaalse entiteediga. Teisalt eksisteerib Ferdinand de Saussure'i poolt loodud rafineeritum märgiteooria, aga see teooria on oma olemuselt suunatud piiratud ainevallale ning ei hõlma neid märke, mis põhinevad analoogiapõhistel assotsiatsioonidel.

Käesoleva artikli peamine eesmärk on näidata, kuidas Saussure’i teooria edasiarendus, mille esmane eesmärk on hõlmata ka analoogial põhinevaid märke, võib pakkuda võimaluse märgiteooria ümberformuleerimiseks. Nii võime me rääkida „neoklassikalisest” innovatiivsest semiootikateooriast, mis on suuteline endas ühendama hilisema „sotsiosemiootilise" lähenemise meie distsipliini oluliste põhialustega. 